\title{
A Reappraisal of Liturgical Continuity in the Mid- Sixteenth Century: Henrician Innovations and the First Books of Common Prayer
}

Repenser la continuité liturgique au milieu du XVIe siècle: les innovations du règne d'Henri VIII et les premières éditions du Book of Common Prayer

\section{Aude de Mézerac-Zanetti}

\section{(2) OpenEdition}

\section{Journals}

Electronic version

URL: http://journals.openedition.org/rfcb/1218

DOI: $10.4000 /$ rfcb.1218

ISSN: 2429-4373

\section{Publisher}

CRECIB - Centre de recherche et d'études en civilisation britannique

\section{Electronic reference}

Aude de Mézerac-Zanetti, «A Reappraisal of Liturgical Continuity in the Mid-Sixteenth Century: Henrician Innovations and the First Books of Common Prayer », Revue Française de Civilisation Britannique [Online], XXII-1 | 2017, Online since 02 May 2017, connection on 03 May 2019. URL : http:// journals.openedition.org/rfcb/1218; DOI : 10.4000/rfcb.1218

This text was automatically generated on 3 May 2019.

\section{c) (†)}

Revue française de civilisation britannique est mis à disposition selon les termes de la licence Creative Commons Attribution - Pas d'Utilisation Commerciale - Pas de Modification 4.0 International. 


\title{
A Reappraisal of Liturgical Continuity in the Mid-Sixteenth Century: Henrician Innovations and the First Books of Common Prayer
}

\author{
Repenser la continuité liturgique au milieu du XVIe siècle: les innovations du \\ règne d'Henri VIII et les premières éditions du Book of Common Prayer
}

Aude de Mézerac-Zanetti

1 For more than a century, eminent scholars, from F.E. Brightman to Brian Cummings, have tirelessly reconstructed the varied influences which contributed to shaping the Book of Common Prayer. ${ }^{1}$ When trying to untangle the multiple sources of the first liturgies in English, much of the focus rightly centres on the different rites from which Archbishop Cranmer drew, as he is usually considered to be the main compiler of the new liturgy. His knowledge in that field was extensive, ranging from the traditional Roman liturgy and its variants (such as the Sarum rite used in most of England) to rarer forms and Continental reformed rites. Charles Whitworth's study of the penitential psalms in this issue is a telling example of how in several instances, the Prayer Book's original Sarum influence survived successive revisions. ${ }^{2}$ The influence of doctrinal statements of Reformed churches on the prayer book has also been highlighted by Brian Spinks while the clear Biblical content has even led scholars such as Alec Ryrie to see the Anglican services as "mechanisms for delivering the English Bible to the people". ${ }^{3}$

2 However, very little attention is paid to the impact of the immediate past. Indeed, worship underwent a few practical changes in Henry's reign. The liturgical developments of the 1530s and 1540s have been woefully neglected and this paper purports to correct this oversight and hence argue that although the 1549 Book of Common Prayer was radically novel and undisputedly broke with the past in many ways, it also presents some degree of continuity with changes implemented in the 1530s and 1540s. In the books and manuscripts surviving from this period, numerous meaningful adjustments to traditional 
forms of worship can be found. Building on these observations, I would like to offer some perspective on the bearing that the immediate past had on the composition of the early Books of Common Prayer.

3 By so doing, I do not mean to deny that the 1549 text departed widely from preReformation liturgical traditions and beliefs and that the Book of Common Prayer was indeed a revolution in worship. But, as Bryan Spinks has established, the English liturgy also evolved through "experimentation and a planned series of orders". He understands the first step of this gradual process to be the "Order of Communion" of 1548, I would contend that, in fact, the first phase of this gradual development can be traced to the 1530s and 1540s. ${ }^{4}$ Not only is the emphasis on continuity in worship central to understanding the developments of Anglican liturgy over the course of the $16^{\text {th }}$ and $17^{\text {th }}$ century, it is also a useful concept when looking at the creation of the Book of Common Prayer. ${ }^{5}$ The notion of experiential continuity can indeed help explain why the revolutionary change of 1549 was quite readily accepted by the English people. This very issue goes to the heart of the underlying anthropological dimension of liturgical practice: rites and rituals provide meaning, shape communities and connect the present with the past and the living with the dead.

4 The relation between the evolution of the liturgy under Henry and the content of the Book of Common Prayer remains hopelessly complex and untidy. The liturgical experimentations of the later years of Henry's reign heralded some of the features implemented in the new liturgy while other Henrician innovations were abandoned or watered down, in particular as concerned the focus on the king's supremacy within liturgical texts. And finally, the most enduring change concerned the function of the liturgy: in this respect, developments and experiments instigated under Henry became staple features of Reformed worship.

\section{Henrician innovations carried over into the Book of Common Prayer}

5 Amongst the liturgical developments of the 1530 s and 1540 s, three found their way into the Reformed liturgy of Edward's reign.

6 The best-known prayer published under Henry VIII and still in use, almost unchanged in Edward's reign, is certainly the new litany of $1544 .{ }^{6}$ In tone and emphasis, Archbishop Cranmer's litany in the vernacular departed radically from the late medieval devotional practice known as the letania which centred on the intercession of the saints. The long list of saints was removed with merely a reference to Mary and saints in general maintained. The prayer was entirely translated into English and preceded by a homiletic text entitled An Exhortation to Prayer. The use of the vernacular and the emphasis on sincerity and understanding as an assurance of efficacy are remarkably consistent with Cranmer's later understanding of the role and function of the liturgy.

7 A cursory foray into the matter would suggest that in some parishes the 1544 litany was still in use at the start of Edward's reign. One parish priest effected manuscript changes to the intercessory section of the litany to pray for Edward instead of Henry and rectified the passage which mentioned Prince Edward to reflect the latter's accession to the throne. ${ }^{7}$ Interestingly, the mention of Mary, the angels and the saints are also deleted from the text, thus aligning it perfectly with the version of the litany published in the 
1549 Prayer Book. ${ }^{8}$ This example shows how liturgical texts could be recycled and adapted to circumstances when a concern for thrift was paired with a desire to conform.

Most commentators agree that the structure of the prayer at the altar which immediately follows the Preface in the 1549 eucharistic liturgy is mainly derived from the Sarum canon of the mass, and Cranmer once inadvertently referred to the consecration prayer as the "canon". ${ }^{9}$ Regardless of the similarities in structure, the theological underpinnings of the two texts are at variance, in particular as concerns the doctrine of the sacrifice of the mass, a notion which was whole-heartedly rejected by the Reformers.

But the ecclesiological content of the text is also slightly different since in the Latin rite, the priest presented the holy offerings:

on behalf of thy holy Catholic Church which do thou vouchsafe to keep in peace, to guard, to unite, and to govern, throughout the whole world; together with thy servants our Pope N. and our bishop N. That is to say the bishop of the diocese only, then shall follow and our King $\mathrm{N}$ and all who are orthodox, and who hold the catholic and apostolic faith. ${ }^{10}$

10 In the first and second Books of Common Prayer, this passage is vastly expanded and the order of the intercession is altered: the prayers are offered to God, beseeching Him to inspire continually the universal church, the king and his council and to give grace to "all Bishoppes, Pastors, and Curates", to comfort all whom suffer and finally to have mercy on the local congregation. In a reversal of the old medieval order, the king (and his council) come before the bishops and the rest of the clergy.

11 Such liturgical implementation of the royal supremacy was first introduced under Henry's reign. In a considerable portion of the surviving missals, the word papa is removed from the canon as it is from elsewhere in the service books. But, in about forty percent of all missals amended under Henry VIII, this very section of the canon was rewritten so as to reflect the advent of the royal supremacy along with its revised ecclesiology. Hence, the king was named before the bishop. These changes were often effected in several stages, the successive alterations to the canon of the mass being a tangible illustration of the gradualism of liturgical change under Henry. That this new practice had become established is further evidenced in the Rationale for Ceremonial written by a committee of bishops, including several stalwart conservatives. ${ }^{11}$ The Henrician practice of naming the king before the bishops provides the missing link to explain this minor yet symbolic shift in order.

12 Finally, the daily use of a collect for the sovereign, which has remained a hallmark of the Anglican liturgy to this day, was in fact introduced by Thomas Cranmer as early as April 1534, months before Parliament passed the Act of Supremacy. The archbishop required that, in his Province, all members of the clergy recite the three orisons (collect, secret and post-communion in the Latin terminology) for the King and for Queen Anne at mass every day. This was certainly thought of as an early means to ensure the clergy's heartfelt commitment to the royal supremacy and to the king's marriage to Anne.

13 In practice, an ad-hoc version of this mass was adopted in the dioceses of Hereford and Worcester. The king's title of supreme head of the church is explicitly mentioned in the collect:

We beseech thee, almighty and merciful God, that thy servant our king Henry the Eighth, on earth supreme head of the English church, who through Thy mercy hath undertaken the government of the kingdom, and your servant Anne, our queen, may also be endued plenteously with all virtues; that being therewith meetly 
arrayed, they may by thy grace be enabled to rejoice in bodily health, escape the whirlpool of vice, overcome their enemies, and that he may govern human things peacefully and that his life may be as happy as possible so that when the course of this life is passed, he may finally attain unto thee, who art the way, the truth, and the life. ${ }^{12}$

If the principle of praying daily for the king at the sacrament of the altar finds its theological justification in the Pauline entreaty to pray for civilian authorities, it also has a more immediate foundation in a practice established and enforced under Henry VIII. Yet the content of the prayer in the Book of Common Prayer of 1549 is not strictly identical to that of its forerunner: the reference to the king's supreme headship of the church is watered down in the 1549 collects: Edward is invoked as "king and governour". The same choice of words was retained in all the ensuing versions. ${ }^{13}$ This example is indicative of the very point where the theology of the Book of Common Prayer parts ways with some Henrician innovations which were narrowly focused on promoting the royal supremacy to the clergy and the realm at large.

\section{Deviations from Henrician practice}

Several prayers and liturgical practices established under Henry VIII were aimed solely at ensuring political loyalty and uniting the realm in prayer for the sovereign. This is particularly true of the new bidding prayers of 1534 and 1536. Archbishop Cranmer banned the rambling, profusely detailed, didactic and eminently parochial bidding of the bedes of the late Middle Ages and replaced them with a streamlined prayer in which the royal supremacy stood front and centre. ${ }^{14}$ The Henrician bidding prayers do not appear in the 1549 liturgy but rather the communal prayer of old may well have contributed to the beginning of the prayer at the altar which is also a prayer for the church militant:

哐...䜿 We humbly beseche thee moste mercyfully to receive these our praiers, which we offre unto thy divine Majestie, beseching thee to inspire continually the universal churche, with the spirite of trueth, unitie, and concorde: And graunt that al they that do confesse thy holy name, maye agree in the trueth of thy holye worde, and in live in unitie and godly love. Speciallye we beseech thee to save and defende thy servaunt, Edwarde our Kyng, that under hym we maye be Godly and quietly governed. And grant unto his whole consaile, and to that he put in authoritie under hym, that they maye truely and indifferently minister justice, to the punishmente of wickedness and vice, and to the maintenaunce of Goddes true religion and vertue. Geve grace (o hevenly father) to all Bishoppes, Pastors and Curates, that thei maie bothe by their life and doctrine set furthe thy true and lively worde and rightely and duely adminster thy holy Sacramentes 堐...區 And we most humby beseche thee of thy goodnes (O Lorde) to coumfort and succour all them, whyche in thys transytory life be in trouble, sorowe, nede, sycknes, or any other adversitie. ${ }^{15}$

Indeed, this long passage bears little resemblance to the Sarum canon of the mass and is rather suggestive of the old bidding prayers with its didactic emphasis on the duties and obligations of all members of society:

Ye shall knell down on your kneis and praie devoutle and mekle to the Fader, the Son and the Holi Gost, three persons and on Gode: to the holy made the moder seynt Marye, and to all the holy court of hevene, specialy for the state and pees of all holy churche and all crysten kyngdoms and especeiall for the kyngdom of Yglond, that Jhu Crist of heven and prynce of pees graunte rest, unite and pees amonge all Cristen pepyll. 
Ye shall praie also for the pope of Roome speciali and all his cardinall, for the Patryake of Jerusalem, for owr lorde and fader the erchebyshope of Canterbury and for owr fader the bysshope of London and all other erchebisshope and bisshope, speciali of this londe, that Jesus Crist geve hem myth and strengthe to mayntene the Staat and lawe of holy Chirche, and for to rewll well hemself and after that prestes and clerkes and all men and women of order and Cristen people Jesu to serve and plees. [...]

Also ye shule praye spicialy for the patron and for the parson of this chirche and for all the prestes and clerkes whiche servene Gode in this chirche or in any other, that Gode of his myche mercy hem helpe and mayntene to his worshype, and graunte hem grace so to do in this worlde, that it may be the savacion of here soules and of alle Cristene folk. [...]

Also yee shall pray hertely for our leggh lorde, Kynge of Ingelond, and for our lady the Quene, and for our prynce whom Crist save gostly; for dukes, erlis, barons knyghtes, squyers, and for all gude communers of this lond, that God yeve hem alle grace so to do and orden so, that it be so soveraynlly likynge to hym and profyt and salvacion of his londe. [...]

Yee shule also pray specialy for the welfayr and prosperite of this worshipefule cyte of London, for my ryth worship and reverente maister our maier, with all my maisters his bretherne aldermen: for the schereffys and all other offycers and dwellers in the shame (same); and specially for oure parishioners here present, yche man prayeth for other and for tham which be absent and walde be present and may gnoth: and for tham that may and wil noth, that God amende tham: and speciale for seek and all that er desesyd in body or in soule, that God of gudnes conforte tham gostly and bodely: and for women that ben with cheldern, that God graunte to tham e gud delyveraunce and purificacion, to there childern crystendome and confirmacion. ${ }^{16}$

17 It is likely that the very bidding prayers which might have inspired the prayer for the church militant has not survived but the broad similarities in tone and emphasis suggest a connection. This hypothesis is bolstered by the change in the organisation of the eucharistic liturgy implemented in the second Book of Common Prayer: the intercessory passage is moved out of the institution narrative and stands immediately after the homily, hence closer to the place of the bidding of the bedes in the Sarum liturgy. The reason why, in this case, the Henrician bidding prayers was jettisoned may be its overemphasis on the royal supremacy while the Edwardian liturgy marks the return of a general intercessory prayer which is more inclusive and communal in tone and didactic in content, two hallmarks of reformed worship in England. It is also a clear-cut case of continuity in worship and liturgical recycling of medieval texts in the Book of Common Prayer.

\section{Changing the function of worship}

Changes in the function of worship are perhaps the most significant examples of how worship in English parish churches moved away from the Catholic tradition into Protestant territory. It also bolsters the claim that liturgical experimentation of the 1540s informed the radically new liturgies of Edward's reign.

Ramie Targoff has aptly summarized one of the anxieties at the core of the Edwardian Reformation: "English Reformers worried openly about the desirability of encouraging physical signs and gestures as part of the worshipper's practice of prayer". ${ }^{17}$ It is well known that between 1549 and 1552, the ritual actions of the liturgy were gradually pared down and worship became less of a performative rite. This is particularly clear in the 
well-rehearsed changes effected to the baptismal liturgy.$^{18}$ However, the first steps in this direction were taken under Henry's reign, as exemplified in the treatment of sacramentals in the doctrinal pronouncements of Henry's church.

In the strictest sense, a sacramental is defined as a prayer, a ritual or an object instituted or acknowledged by the Church, such as the use of holy water, holy bread, blessed candles, ashes, etc. Sacramentals share a common efficacy with good works as they prepare the soul to receive grace. ${ }^{19}$ Worthy reception of sacramentals grants remission of venial sin along with spiritual or material graces. The liturgy of sacramentals usually subtly combines complex deprecatory phrases, assertions of spiritual efficacy and demands for apotropaic and prophylactic benefits. At the turn of the 16th century, these rituals remained popular and were considered an important aspect of Christian devotion. 20

21 To take but one example, at Sunday mass, the priest exorcised salt and water, before mixing and blessing these elements which constitute holy water. In this prayer, three types of requests were made: for spiritual benefits (the salvation of the believers, the gift of the Holy Spirit), for material blessings (good health) and for apotropaic favours which were expected from the blessed elements (chasing evil and demons). The blessing itself presents several layers of meaning: the allegorical reminder of Christ's baptism and Elisha's healing of a spring with salt, and the symbolic reference to the water used in baptism and the eucharist. But emphasis is firmly placed on the performative powers of the liturgical formulae; the assurance was given that holy water healed soul and body, purified places and put the devil to rout. In fact, to a large extent, the liturgy legitimated the quasi-magical uses of holy water, thus creating the mix of superstition and accepted religious beliefs which Eamon Duffy has termed 'lay Christianity'. ${ }^{21}$ Prophylactic use of the sacramental was very common, as it served as a remedy for many ills, and criticism of such usage must be carefully scrutinized as it often served polemical purposes. ${ }^{22}$ In truth, holy water was the most sought after and regularly used sacramental until the 1530s.

Under Henry, however, the meaning of sacramentals was deeply altered. In the "Ten Articles" of 1536, they are treated as symbols, justifying a purely allegorical understanding of the ceremony: 'sprinkling of holy water [is] to put us in remembrance of our baptism, and the blood of Christ sprinkled for our redemption upon the cross'. ${ }^{23}$ The general understanding of sacramentals is subtly refashioned, as they are

to be used and continued as things good and laudable, to put us in remembrance of those spiritual things that they do signify; not suffering them to be forgot, or to be put in oblivion, but renewing them in our memories from time to time. But none of these ceremonies have power to remit sin, but only to stir and lift up our minds unto God, by whom only our sins be forgiven..$^{24}$

The new teaching on sacramentals constituted a radical simplification of the multiple layers of meanings conveyed by the Latin texts. The clergy were thus required to use these rituals all the while explaining that they were not efficacious of themselves but merely reminders of higher spiritual realities.

Liturgical rituals became teachable moments and were kept for their catechetical value and to preserve public order. This hermeneutic evolution necessarily translated into liturgical practice, since performing the same rituals while expecting them to mean something different would necessarily create a disjunction.

Some members of the clergy were thus exploring new ways of meaningfully performing these rituals. It appears that Hugh Latimer, a committed Reformer and later a victim of 
Marian persecutions, encouraged the clergy of his diocese to use a new text in the vernacular when performing the rite of sprinkling holy water on the faithful:

Remember your promise in baptisme,

Christ his mercy and bloudshedding,

By whose most holy sprinkeling

Of al your sinnes you haue free pardoning. ${ }^{25}$

This work would probably have replaced the Asperges me ritual. Here, the new teaching on the sacramentals was duly channelled through the purely allegorical treatment of holy water. The ritual was interpreted as a reminder of baptism and the water stood in the stead of the holy blood of Christ which alone granted forgiveness and salvation: in Latimer's verses, the phrase 'most holy sprinkling' applied to the blood of Christ on the cross, of which the water was a mere sign. This example goes to show that in the more evangelical parishes of the diocese of Worcester, the liturgical texts accompanying the ritual of holy water might have evolved significantly in the late 1530s at the behest of one of the more radical reforming bishops. And the use of a text very similar to this one is attested at Arlingham in Latimer's diocese. ${ }^{26}$

The issue of efficacy in the liturgy was not circumscribed to these ceremonies, as some of the seven sacraments came to be considered in much the same light as sacramentals: confession, confirmation and extreme unction were omitted from the Ten Articles and later described in the Bishops' Book and the King's Book as efficacious when received worthily. The notion of worthy reception was already altering the traditional teaching on sacraments long before the Protestant Reformation took hold in England.

Finally, liturgical practice starkly divided conservatives from evangelicals and threatened the unity of parishes For instance, disputes over the use of holy water were front and centre in the 1543 inquiry into Kentish heretics. Conservatives encouraged traditional understanding and practice ${ }^{27}$ while evangelicals stopped blessing water, banned their parishioners from using it, indeed sometimes mocked this practice. ${ }^{28}$ Contestation of sacramentals peaked when radical laymen and women rejected these traditional rites. Members of the Toftes family of Northgate, Canterbury engaged in illegal iconoclasm, refused to bear palms and to creep to the cross, read the Bible aloud in church, declared images to be devils, threatened to set fire to the church and harboured people who had 'made themselves priests and were none. ${ }^{29}$ Margaret Toftes the younger declared that "her daughter could piss as good holy water as the priest could make any" and warned the parish clerk's servant not to bring any holy water to her house saying the water in her well was as good. ${ }^{30}$ light on the roots of some of Anglican idiosyncrasies while revealing much about the differences between Henry's and Edward's brands of Reformation. The Edwardian Reformation is rightly seen as infinitely broader and more spiritual in nature than the ecclesiological revolution of the 1530s. However different, the two moments can also be seen as a continuous process by which the English reformers were weaning the English from the Catholic liturgy: implementing change gradually, undermining traditional rites before removing them completely and often, in the phrase of Diarmaid MacCulloch "promoting reform within the shell of traditional forms".

Willingly or not, Henry had set this process into motion well before his death. Indeed, the king's policy of compromise, by authorising traditional practices while shifting their meaning, inadvertently created a growing disjunction between prayer and doctrine, 
weakening people's trust in the liturgy. Along with acceptance that the king had the authority to approve if not define acceptable forms of worship for his Church, came the idea that the liturgy was contingent and its content no longer immutable. Finally, without meaning to sound despondent, it is my understanding that the challenge levelled at the liturgy contributed to its demise as a source of faith. In fact, the growth of the king's control over the liturgy dovetailed the decline of trust in the power of prayer. The combination of these two factors may contribute to the ongoing conversation about the origins of the Edwardian Reformation and help explain why the wholesale revision and translation of the liturgy was more readily accepted by most English people in 1549 than might have been expected in view of the strength of the Catholic faith on the eve of the Reformation. ${ }^{31}$

\section{NOTES}

1. See Introduction, note 1 and 6.

2. Charles Whitworth, "The Penitential Psalms and Ash Wednesday Services in the Book of Common Prayer, 1549-1662", in this volume.

3. Bryan D. Spinks, "Treasures Old and New: A Look at Some of Thomas Cranmer's Methods of Liturgical Compilation", Thomas Cranmer: Churchman and Scholar, ed. Paul Ayris and David Selwyn (Woodbridge: Boydell Press, 1993). See the same author's Reformation and Modern Rituals and Theologies of Baptism: from Luther to Contemporary Practices (Aldershot: Ashgate, 2006). Alec Ryrie's quotation is taken from a lecture delivered in Carlisle Cathedral for the celebration the $350^{\text {th }}$ anniversary of the 1662 Book of Common Prayer. The lecture can be found http:// alecryrie.blogspot.fr/2012/09/the-prayer-book-at-carlisle.html

4. Bryan D. Spinks, "Treasures Old and New", op. cit., 176

5. See in this volume: Claire Cross, "The political enforcement of liturgical continuity in the Church of England 1558-1662".

6. An exhortation vnto prayer thought mete by the kinges maiestie, and his clergy, to be read to the people in euery church afore processyions. Also a letanie with suffrages to be said or song in the tyme of the said processyons, London: Berthelet, 1544 (STC 10620). For a thorough and brief examination of the Litany, see Diarmaid MacCulloch, Thomas Cranmer, A Life (New Haven \& London: Yale, 1996), 328-332. See also Proctor and Frere, A New History of the BCP, op. cit., 405-429 for a historical overview of the use of the litany in the Church and Roger Bowers. "The Vernacular Litany of 1544 During the Reign of Henry VIII" in Authority and Consent in Tudor England, ed. G.W. Bernard \& S. J. Gunn (Aldershot: Ashgate, 2002), 151-178.

7. An exhortation vnto prayer... Also a letanie, London: Berthelet, 1544, STC 10622 (available on EEBO), fo. B v.

8. ibid. fo. B ii.

9. Diarmaid MacCulloch, Cranmer, op. cit., 413.

10. The English translation is taken from The Sarum Missal in English, trans. Fredetick E. Warren (London: De La More Press, 1911), part I, 42. The original Latin reads: "In primis quæ tibi offerimus pro ecclesia tua sancta Catholica, quam pacificare, custodire, adunare et regere digneris toto orbe terrarum, una cum famulo tuo Papa nostro N. et Antistite nostro N. (id est proprio episcopo tantum) et Rege nostro N. (et dicuntur nominatim) Sequatur et omnibus orthodoxis 
atque catholicæ et apostolicæ fidei cultoribus." For a modern edition of the Sarum missal, Missale ad usum insignis et praeclare ecclesiae Sarum, ed. F.H. Dickinson (Bruntisland: E Prelo de Pitsligo, 1861-1883), col. 613-614.

11. C. S. Cobb, ed., The Rationale of Ceremonial or Book of Ceremonies, Alcuin Club Collections (London Longman, 1910), 24.

12. The translation is mine. The original Latin text is found added to two Hereford missals (Oxford, Bodleian, Arch. B. c.6 and Oxford, St John's College, Cpbd.b.2.upper shelf.1). A similar mass is found in the missal which belonged to Hereford Cathedral (Worcester Cathedral Library MS F161). For a modern edition of the text, see Missale ad usum percelebris ecclesiae Herefordensis, op.cit., p. iii-iv: Quaesumus, omnipotens et misericors Deus, ut famulus 區tuus Henricus octavus, in terris ecclesiae Anglicanae supremum caput, qui tua miseratione suscepit regni gubernacula, et famula tua Anna, regina nostra, virtutum omnium percipiat incrementa ; quibus decenter ornati corporis incolumitate gaudere et vitiorum voraginem devitare, hostes superare, ac in tranquilla pace dum in humanis agent, tam feliciter possint sua tempora pertransire, ut post hujus vite decursum, ad te qui via, veritas, et vita es, gratiosi valeant pervenire.

13. Brian Cummings, ed., The Book of Common Prayer, 21 (1549), 126 (1552 and 1559) and 391-2 (1662)

14. BL, MS Cotton, Cleopatra V, fo 286. For a slightly different version of this text see the injunctions in Latin sent to monasteries: BL MS Cleopatra IV fo. $11 \mathrm{v}$.

"First, Whosoever shall preach in the presence of the king's highness and the queen's grace, shall in the bidding of the beads, pray for the whole catholic church of Christ, as well quick as dead, and specially for the catholic church of this realm: and first, as we be most bounden, for our sovereign lord king Henry the VIIIth, being immediately next unto God the only and supreme head of this catholic church of England, and for the most gracious lady queen Anne his wife; and for the lady Elizabeth, daughter and heir to them both, our princess, and no further.

Item, The preacher in all other places of this realm, than in the presence of the king's said highness and the queen's grace, shall, in the bidding of the beads, pray first in manner and form, and word for word, as is above ordained and limited; adding thereunto in the second part, for all archbishops and bishops, and for all the whole clergy of this realm; and specially for such as shall please the preacher to name in his devotion: and thirdly, for all dukes, earls, marquisses, and for all the whole temporality of this realm; and specially for such as the preacher shall name of devotion: and finally for the souls of all them that be dead, and specially of such as it shall please the preacher to name."

15. ibid., 31 (1549).

16. These bidding prayers are taken from British Library Harleian MS 335. For a modern edition, see Manuale et Processionale ad usum insignis ecclesiae eboracensis (Surtees Society, 1875), 223*-225*.

17. Ramie Targoff, Common Prayer: The Language of Public Devotion in Early Modern England (Chicago: Chicago University Press, 2001), 9.

18. This methodology is typical of Cranmer's approach to liturgical reform and a similar evolution may be observed in the rite of baptism between 1549 and 1552. At first several distinctive ritual elements were kept: an exorcism, the triple effusion, the white garment, the annointing and the blessing of holy water in the font.

The language used in the first BCP was still somewhat performative ("I commaunde thee, uncleane spirite, in the name of the father, of the sonne, and of the holy ghost, that thou come out, and departe from these infants"). But these ritual aspects were forsaken in the 1552 BCP with only one brief mention of the water in the liturgy but no blessing or sacring of the element.

19. The Ordynary of Christen men, sig. $\mathrm{C}$ ii.

20. Eamon Duffy, The Stripping of the Altars, op. cit., 277-287.

21. Eamon Duffy, The Stripping of the Altars, op. cit., 283 
22. The use of holy water as a remedy for piles is condemned (Letters and Papers, xviii, (ii) (546), 293). Drinking holy water is forbidden in the King's Book and sprinkling it on beds banned in Cranmer's 1547 Injunctions to his diocese (Lloyd, Formularies of Faith, op.cit., 298, and Visitation Articles and Injunctions, op. cit., 187).

23. Formularies of Faith, xxviii.

24. Ibid.

25. John Foxe, Acts and Monuments (London, 1563), 1417, see The Unabridged Acts and Monuments Online (1563), available from : www.johnfoxe.org.

26. See Arlingham Breviary, Salisbury Cathedral MS 152. For a modern edition of the prayer used during the sprinkling of holy water see H.T. Kingdon's "On an early vernacular service,"The Wiltshire Archeological and Natural History Magazine XVIII n LII: 62-70. I disagree with his view that this is a late $15^{\text {th }}$ century text which inspired Hugh Latimer's revised ritual.

27. Letters and Papers, xviii, (ii) (546), 296, 300, 308

28. Ibid., 295, 291, 306-7, 311.

29. Ibid.

30. Ibid., 307.

31. The question of the causes of the success of Edward's Reformation is at the heart of the work of post-revisionist historians of the Reformation. See Ethan Shagan, Popular Politics and the English Reformation (Cambridge: CUP, 2002), 2; Alex Ryrie, The Gospel and Henry VIII: Evangelicals in the Early English Reformation (Cambridge: CUP, 2003), 7.

\section{ABSTRACTS}

The multiple sources of the first two versions of the Book of Common Prayer have received a lot of attention from scholars. Thomas Cranmer, who was their principal compiler, had indeed turned to diverse texts for inspiration: the Sarum rite of his province of Canterbury and Scripture were obvious sources, as were the several ancient liturgical traditions of which the archbishop had knowledge. This article however explores more immediate origins for the English liturgies, i.e. the new practices created at the end of Henry VIII's reign.

After the break with Rome and the passing of the Act of Supremacy of 1534, liturgical experiments were rife in England as the regime harnessed public prayer to advertise the royal supremacy and the clergy responded by adapting the Catholic liturgy to the new ecclesiology and the revised doctrinal pronouncements. Several of the new prayers composed under Henry were included in the Book of Common Prayer, albeit in a slightly modified version (bidding of the bedes, 1543 litany). Moreover, changes in the clergy's liturgical habits also shed light on the origins of some passages found in the Edwardian liturgies.

This article also seeks to illuminate one of the most enduring historiographical issues relating to the English Reformation: why was the wholesale liturgical reform of 1549 so readily accepted or tolerated by a majority of the English people? A better understanding of how the Henrician Reformation redefined the status of the liturgy may contribute to explaining the success of the Edwardian liturgical reforms, for public prayer had lost its status as an immutable and trustworthy depository of faith and had become a text which could be reformed at will by the government. 
Les sources du Book of Common Prayer sont nombreuses et ont été largement étudiées par historiens et liturgistes: Thomas Cranmer, principal auteur de la version de 1549 a, en effet, trouvé son inspiration dans les Ecritures, le rite de Salisbury (Sarum) et les diverses traditions liturgiques dont il avait une fine connaissance.

Mais les expérimentations liturgiques qui eurent cours sous le règne d'Henri VIII, à la suite du schisme de 1534, ont également influencé la composition de certains passages de la nouvelle liturgie. Le régime d'Henri VIII a exploité la liturgie comme moyen de communication pour faire connaître la suprématie royale. Le clergé a servi de courroie de transmission et promptement mis en œuvre cette nouvelle ecclésiologie

Or certaines de ces nouvelles prières, comme les oraisons pour le roi et les nouvelles prières d'intercession, composées afin d'introduire la suprématie royale dans la prière de l'Eglise sont ensuite introduites dans les deux éditions successives du Book of Common Prayer.

Enfin, plus largement, les effets des expérimentations liturgiques des dix dernières années du règne d'Henri VIII peuvent contribuer à éclairer une des questions historiographiques les plus fondamentales de l'étude du début de la Réforme en Angleterre : pourquoi et comment cette révolution liturgique fut-elle si aisément acceptée dans le royaume? La conception de la liturgie comme un dépôt de la foi avait été érodée par la tolérance de pratiques hétérodoxes et par la remise en question par le régime lui-même de cette source dogmatique.

INDEX

Mots-clés: Réforme anglaise, Henri VIII, liturgie, Book of Common Prayer Keywords: English Reformation, Henry VIII, liturgy, Book of Common Prayer 